\title{
ANALISIS MANAJEMEN RISIKO KESELAMATAN DAN KESEHATAN KERJA LINGKUNGAN MUTU PROYEK JALAN TOL DAN JEMBATAN PADA PT. HUTAMA KARYA INFRASTRUKTUR DI KOTA DEPOK
}

\author{
(Risk Analysis of Occupational Health and Safety Environmental and Quality The Construction of the Toll \\ Roads and Bridge at PT. Hutama Karya Infrastruktur in Depok City) \\ Ramadhan Syahriadi ${ }^{1}$, Andi Tenrisukki Tenriajeng ${ }^{2}$ \\ ${ }^{1}$ Magister Teknik Sipil, Program Pascasarjana, Universitas Gunadarma ${ }^{2}$ Program Studi Teknik Sipil, \\ Universitas Gunadarma
}

Perum. Griya Parungpanjang, Blok F1/E No.18, Kec. Parungpanjang. Kab. Bogor 16360

E-mail: ramadhan.syahriadi@gmail.com

\begin{abstract}
ABSTRAK
Pembangunan jalan tol dapat meningkatkan efisiensi transportasi dan dapat meningkatkan perekonomian di suatu wilayah. Pelaksanaan pembangunan jalan tol tidak akan lepas dari risiko. Kemungkinan kecelakaan kerja yang terjadi dalam proyek konstruksi akan menjadi salah satu penyebab kegiatan kerja proyek terganggu. Penelitian ini dilakukan untuk menganalisis risiko keselamatan dan kesehatan kerja dan lingkungan mutu pada tahap pelaksanaan pembangunan jalan tol dan cara mitigasi/penanganannya sehingga dapat meminimalisir dampak negatif. Metode penelitian yang digunakan yaitu Analytic Hierarchy Process (AHP) dan dengan program SPSS. Hasil analisis didapat 5 variabel risiko tinggi (high), 41 risiko sedang (medium), dan 19 risiko rendah (low). Risiko dengan level tinggi (H) yaitu terjadinya kebakaran BBM (X10), terkena utilitas dibawahnya (pipa gas / air) (X19), girder yang diangkat terjatuh (X50), pekerja tertimpa pipa tremi (X51), dan pekerja jatuh dari ketinggian (X54). Semua risiko dominan tersebut ditangani melalui tindakan preventif dan tindakan korektif. Risiko yang dominan tersebut kemudian dilakukan mitigasi melalui tindakan preventif dan tindakan korektif.
\end{abstract}

Kata kunci: Manajemen Risiko, Keselamatan dan Kesehatan Kerja Lingkungan Mutu, Metode AHP, Penanganan Risiko

\section{ABSTRACT}

Construction of Toll Road can improve the efficiency of transportation and will increase the economy in a region. The construction of the Toll Road can't be separated from risks. The possibility of work accidents that occur in construction projects will be one of the causes of interrupted project work activities. The research was conducted to analyze the risks occupational health and safety and environmental and quality at the stage of the implementation of Toll Road construction and mitigation to minimize negative impact. The research method used is Analytic Hierarchy Process (AHP) and with SPSS program. The result of analyze is 5 high risk factors (High), 41 medium risk factors (Medium), and 19 low risk factors (Low). Risk with high level $(H)$ is there was a BBM fire (X10), affected by utilities below (gas / water pipe) (X19), the fall of the girder when lifted (X50), workers are hit by tremie pipe / concrete pump (X51), and workers fall from a height (X54). Then the dominant risk will be mitigate with preventive actions and corrective actions.

Keywords: Risk Management, Occupational Health and Safety Environmental and Quality, Analytic Hierarchy Process, Risk Mitigation. 


\section{PENDAHULUAN}

Perkembangan industri konstruksi yang pesat selain memberikan manfaat juga dapat menimbulkan risiko, adanya kemungkinan kecelakaan yang terjadi pada proyek konstruksi akan menjadi salah satu penyebab terganggunya atau terhentinya aktivitas pekerjaan proyek (Ervianto, 2005).

Keselamatan dan kesehatan kerja harus dijadikan hal yang penting dalam suatu proyek konstruksi karena dampak kecelakaan dan penyakit kerja yang bisa saja timbul tidak hanya merugikan tenaga kerja saja tetapi juga perusahaan itu sendiri baik itu secara langsung maupun tidak langsung. Pengabaian faktor tersebut dapat mengakibatkan tingginya tingkat kecelakaan kerja pada proyek konstruksi, sehingga akan menambah biaya asuransi tenaga kerja dan mempengaruhi kinerja proyek (Richard H. Clough, 1986).

Di Indonesia telah ditetapkan beberapa peraturan mengenai keselamatan dan kesehatan kerja lingkungan, diantaranya yaitu Undang-Undang No. 1 Tahun 1970 tentang Keselamatan Kerja dan Peraturan Menteri Pekerjaan Umum No. 05/PRT/M/2014 tentang Pedoman Sistem Manajemen Keselamatan dan Kesehatan Kerja Konstruksi. Peraturan tersebut ditetapkan bertujuan untuk mencegah dan mengantisipasi terjadinya kecelakaan kerja. Standar keselamatan dan kesehatan kerja yang belum memadai dan masih tingginya angka kecelakaan kerja di Indonesia, merupakan bukti lemahnya perhatian terhadap pentingnya aspek keselamatan dan kesehatan kerja pada pekerjaan konstruksi. Sebagai gambaran, data angka kecelakaan kerja dari Badan Penyelenggara Jaminan Sosial (BPJS) Ketenagakerjaan hingga akhir Tahun 2015 di Indonesia tercatat 105.182 kasus kecelakaan kerja, dimana terdapat 2.375 orang meninggal dunia. Penyebab terjadinya kecelakaan kerja paling banyak terjadi pada sektor industri konstruksi

Studi kasus dalam penelitian ini dilakukan pada proyek konstruksi pembangunan Jalan Tol Cijago Seksi 2A, Tol Cijago Seksi 2B, dan Pembangunan Jalan dan Jembatan Rumah Sakit Pendidikan Universitas Indonesia. Penelitian ini akan menganalisis risiko dan respon risiko yang terjadi pada manajemen keselamatan dan kesehatan kerja lingkungan mutu proyek konstruksi jalan tol dan jembatan.

Tujuan dari penelitian ini adalah menganalisis berapa besar level risiko manajemen keselamatan dan kesehatan kerja lingkungan dan mutu pada setiap variabel dan faktor risiko dominan yang terjadi, serta bagaimana penanganan berupa tindakan preventif dan korektif terhadap risiko dominan pada pelaksanaan proyek konstruksi pembangunan jalan tol dan jembatan.

\section{METODE PENELITIAN}

Tahapan-tahapan dari proses penelitian ini adalah sebagai berikut:

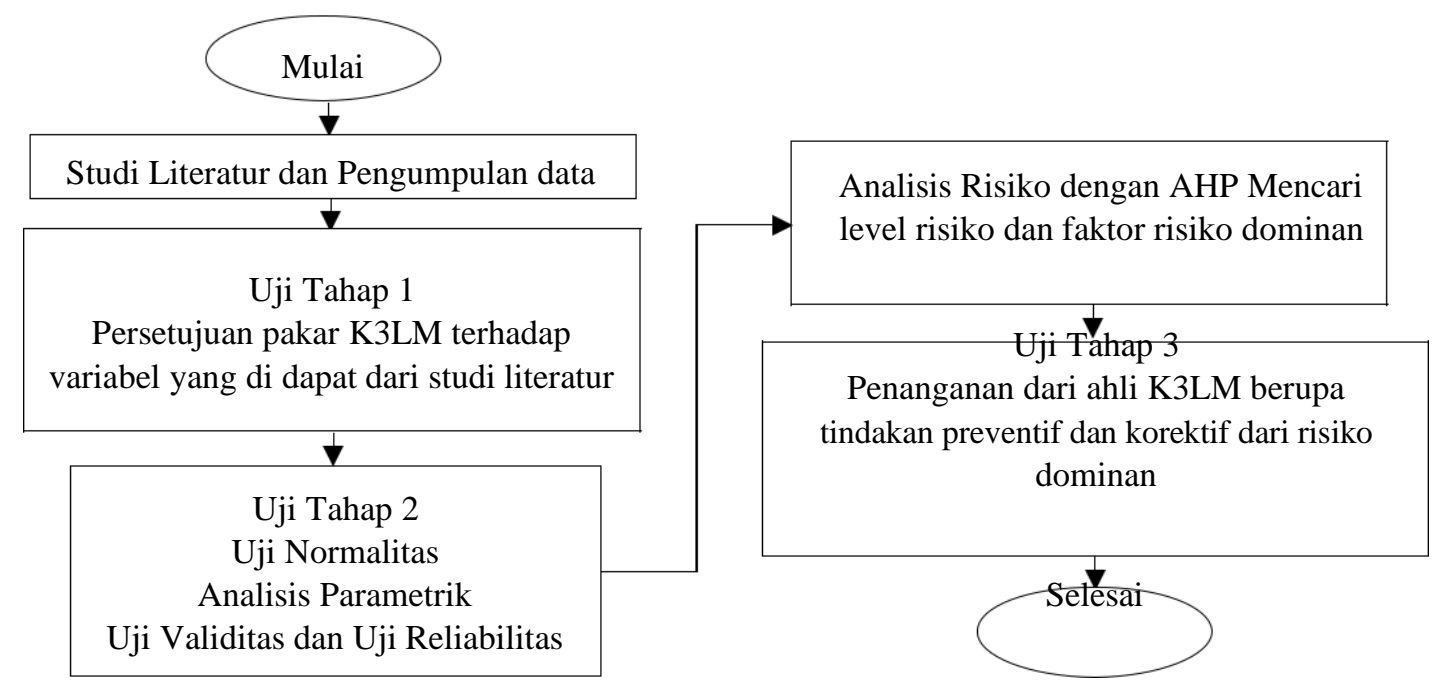

Gambar 1. Diagram Alir Penelitian

\section{Gambaran umum objek penelitian}

Objek penelitian pada penelitian ini adalah proyek konstruksi Jalan Tol Cijago Seksi 2A, Tol Cijago

Seksi 2B, dan Pembangunan Jalan dan Jembatan Rumah Sakit Pendidikan Universitas Indonesia. 
Tabel 1. Objek Penelitian.

\begin{tabular}{llc}
\hline \multicolumn{1}{c}{ Nama Proyek } & Fungsi Proyek & Nilai Kontrak \\
\hline Jalan Tol Cijago & Jalan Tol & Rp. 420.011.290.089,71,- \\
$\begin{array}{l}\text { Seksi 2A } \\
\text { Jalan Tol Cijago }\end{array}$ & Jalan Tol & Rp. 170.921.377.043,02,- \\
$\begin{array}{l}\text { Seksi 2B } \\
\text { Pembangunan Jalan dan }\end{array}$ & Jalan dan Jembatan & Rp. 35.682.212.732,10,- \\
Jembatan RSPUI &
\end{tabular}

Sumber: PT. Hutama Karya Infrastruktur

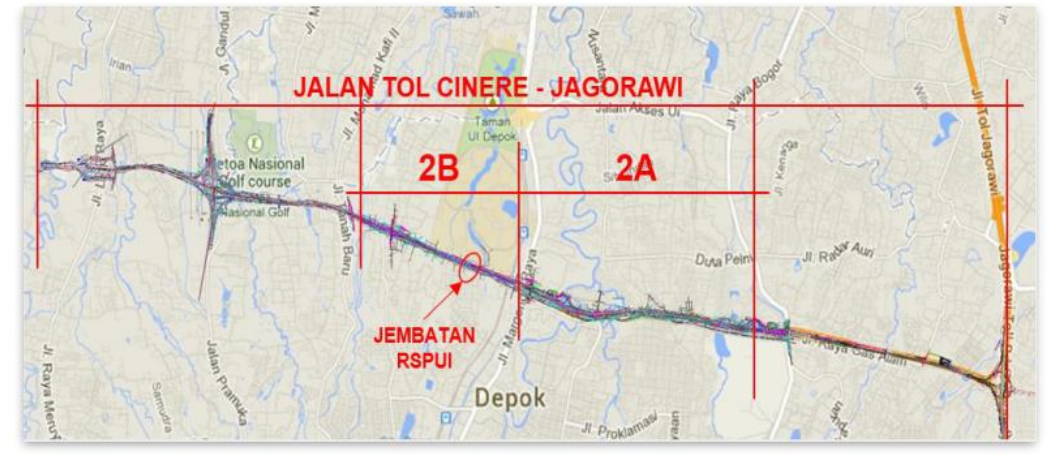

Sumber: PT. Hutama Karya Infrastruktur

Gambar 2. Lokasi Objek Penelitian.

\section{Sampel Penelitian}

Sampel penelitian ini yaitu staff dan pekerja pada PT. Hutama Karya Infrastruktur, dengan banyaknya responden sebesar 39 orang.

\section{HASIL DAN PEMBAHASAN}

\section{Variabel Penelitian}

Variabel penelitian diperoleh dari studi literatur (buku ataupun jurnal) dan wawancara dengan narasumber yang terkait. Kemudian dilakukan uji tahap satu untuk memvalidasi variabel penelitian oleh beberapa pakar guna mendapatkan data variabel yang sebenarnya. Adapun variabel utama penelitian yang telah di validasi oleh pakar adalah sebagai berikut:

Tabel 2. Variabel Utama Penelitian.

\begin{tabular}{|c|c|c|c|}
\hline No. & Kode & $\begin{array}{c}\text { Peristiwa yang } \\
\text { Memungkinkan Terjadinya } \\
\text { Risiko }\end{array}$ & Variabel \\
\hline \multirow{13}{*}{1} & & & Umum \\
\hline & $\mathrm{X} 1$ & \multirow{4}{*}{ Mobilisasi Alat } & Pekerja terkena manuver alat \\
\hline & $\mathrm{X} 2$ & & Pekerja tertimpa alat pada saat loading/unloading \\
\hline & $\mathrm{X} 3$ & & Kerusakan jalan umum yang di lalui \\
\hline & $\mathrm{X} 4$ & & Timbulnya kemacetan lalu lintas jalan umum \\
\hline & $\mathrm{X} 5$ & \multirow{4}{*}{ Laboratorium } & Pekerja terhirup debu bahan berbahaya \\
\hline & $\mathrm{X} 6$ & & Kulit pekerja terkena bahan berbahaya \\
\hline & $\mathrm{X} 7$ & & Penggunaan alat listrik \\
\hline & $\mathrm{X} 8$ & & Penggunaan alat mekanis \\
\hline & $\mathrm{X} 9$ & \multirow{2}{*}{$\begin{array}{l}\text { Loading/Unloading BBM } \\
\text { (Persiapan Pengisian Solar) }\end{array}$} & Terjadi tumpahan/kebocoran pada selang tangki BBM \\
\hline & $\mathrm{X} 10$ & & Terjadi kebakaran BBM \\
\hline & $\mathrm{X} 11$ & \multirow{2}{*}{ Pembersihan Tempat Kerja } & Pekerja tertabrak excavator pada saat land clearing \\
\hline & $\mathrm{X} 12$ & & Gangguan pernafasan pekerja akibat debu \\
\hline \multirow{3}{*}{2} & & & ekerjaan Bongkaran \\
\hline & $\mathrm{X} 13$ & \multirow{2}{*}{ Pembongkaran Pasangan Batu } & Pekerja terkena/tertimpa pecahan batu \\
\hline & $\mathrm{X} 14$ & & Pekerja terjepit batu \\
\hline
\end{tabular}




\begin{tabular}{|c|c|c|c|}
\hline & $\mathrm{X} 15$ & \multirow{3}{*}{$\begin{array}{l}\text { Pembongkaran Perkerasan Jalan } \\
\text { Aspal/Beton }\end{array}$} & Pekerja tertimpa pecahan aspal/beton \\
\hline & $\mathrm{X} 16$ & & Pekerja tertabrak swing excavator \\
\hline & $\mathrm{X} 17$ & & Getaran / suara di atas $85 \mathrm{db}$ \\
\hline \multirow{4}{*}{3} & & & Pekerjaan Tanah \\
\hline & $\mathrm{X} 18$ & & Pekerja tertabrak swing excavator \\
\hline & X19 & Galian untuk timbunan (dengan & Terkena utilitas dibawahnya (pipa gas / air) \\
\hline & $\mathrm{X} 20$ & & Pekerja tertabrak mobilisasi dump truck \\
\hline \multirow{12}{*}{4} & & & Pekerjaan Drainase \\
\hline & $\mathrm{X} 21$ & & Pekerja tertabrak swing excavator \\
\hline & $\mathrm{X} 22$ & & Pekerja tertabrak manuver hyap crane \\
\hline & X23 & Pipa gorong-gorong beton & Material yang diangkut hyap crane terjatuh / sling putus \\
\hline & X24 & & Gangguan mata/kulit cipratan cor beton \\
\hline & $\mathrm{X} 25$ & & Pekerja terluka akibat alat kerja (bar bender/cutter) \\
\hline & $\mathrm{X} 26$ & & Pekerja tertabrak swing excavator pada saat galian \\
\hline & $\mathrm{X} 27$ & Saluran Beton Precast & Pekerja tertabrak manuver hyap crane \\
\hline & $\mathrm{X} 28$ & & Material yang diangkut hyap crane terjatuh / sling putus \\
\hline & X29 & & Pekerja tertabrak swing excavator pada saat galian \\
\hline & X30 & Saluran Pasangan Batu & Pekerja tertimpa batu \\
\hline & $\mathrm{X} 31$ & & Gangguan mata/kulit cipratan cor beton \\
\hline \multirow{4}{*}{5} & & & Pekerjaan Subgrade \\
\hline & $\mathrm{X} 32$ & & Elevasi tanah dengan motor grader \\
\hline & X33 & Persiapan Tanah Dasar & Pemadatan tanah dengan vibro roller \\
\hline & X34 & & Getaran / suara di atas $85 \mathrm{db}$ \\
\hline \multirow{5}{*}{6} & & & Pekerjaan Subbase \\
\hline & $\mathrm{X} 35$ & & Hampar agregat dengan dump truck \\
\hline & X36 & I anic Pondaci A areost t & Elevasi tanah dengan motor grader \\
\hline & X37 & Lapis Pondasi Agregat & Pemadatan tanah dengan vibro roller \\
\hline & X38 & & Getaran / suara di atas $85 \mathrm{db}$ \\
\hline \multirow{8}{*}{7} & & & Pekerjaan Perkerasan \\
\hline & X39 & & Pekerja tertabrak manuver truck mixer saat hampar beton \\
\hline & $\mathrm{X} 40$ & Lean Concrete dan Rigid & Pekerja terjepit alat wirtgen \\
\hline & $\mathrm{X} 41$ & Pavement & Gangguan mata/kulit akibat cipratan cor beton \\
\hline & $\mathrm{X} 42$ & & Pekerja terluka akibat alat kerja (bar bender/cutter) \\
\hline & $\mathrm{X} 43$ & & Gangguan pernafasan akibat aspal dan pembersihan debu \\
\hline & X44 & Perkerasan Aspal & Pekerja terkena aspal panas \\
\hline & $\mathrm{X} 45$ & & Pekerja terkena manuver tandem roller \\
\hline \multirow{10}{*}{8} & & & Pekerjaan Struktur \\
\hline & $\mathrm{X} 46$ & & Longsornya galian \\
\hline & X47 & & Pekerja terluka akibat alat kerja \\
\hline & $\mathrm{X} 48$ & & Pekerja tertabrak swing alat berat bor pile \\
\hline & X49 & & Pekerja tergores/tertusuk besi tulangan \\
\hline & X50 & Pekerjaan Konstruksi Jembatan & Girder yang diangkat terjatuh \\
\hline & X51 & & Pekerja tertimpa tremie/concrete pump \\
\hline & X52 & & Pekerja tertabrak manuver truck mixer \\
\hline & X53 & & Gangguan mata/kulit akibat cipratan cor beton \\
\hline & X54 & & Pekerja jatuh dari ketinggian \\
\hline \multirow{13}{*}{9} & & & Pekerjaan Lain-lain \\
\hline & $\mathrm{X} 55$ & Penanaman Pohon & Pekerja tersengat binatang \\
\hline & X56 & Pasang Guard Rail & Pekerja terluka akibat alat kerja \\
\hline & X57 & Pemasangan Con crete Rarriar & Pekerja tergores/tertusuk besi tulangan \\
\hline & X58 & Pemasangan Concrete Barrier & Pekerja terluka akibat alat kerja \\
\hline & X59 & & Pekerja tertimpa tiang lampu \\
\hline & X60 & Pencahayaan Lalu lintas dan & Pekerja tersengat aliran listrik \\
\hline & X61 & & Pekerja tersambar petir \\
\hline & X62 & & Pekerja terkena manuver loader \\
\hline & X63 & Aktifitas batching plant & Kontaminasi debu semen/agregat \\
\hline & X64 & & Tumpahan beton \\
\hline & X65 & Pemindahan utilitas umum & Terganggunya utilitas warga \\
\hline & X67 & Pemindahan fasos/fasum & Terganggunya fasos/fasum warga \\
\hline
\end{tabular}




\section{Uji Normalitas}

X68 Pemagaran batas area proyek Terputusnya aksesibilitas lokal \& wilayah

Uji Normalitas dapat dilakukan dengan beberapa uji statistik data, dimana pada penelitian ini menggunakan Uji Normalitas Shapiro-Wilk dengan program SPSS 24. Uji Normalitas dilakukan pada normalitas frekuensi dan normalitas dampak. Adapun hasilnya yaitu sebagai berikut:

Tabel 3. Hasil Uji Normalitas Shapiro-Wilk.

\begin{tabular}{ccccccc}
\hline \multicolumn{3}{c}{ Tests of Normality } \\
\hline & \multicolumn{3}{c}{ Kolmogorov-Smirnov ${ }^{\mathrm{a}}$} & \multicolumn{3}{c}{ Shapiro-Wilk } \\
\cline { 2 - 7 } & Statistic & df & Sig. & Statistic & df & Sig. \\
\hline Frekuensi_Risiko & .085 & 39 & .200 & .981 & 39 & .742 \\
Dampak_Risiko & .117 & 39 & .200 & .946 & 39 & .061 \\
\hline
\end{tabular}

\section{Analisis Parametrik}

Hasil pengumpulan data tahap kedua diuji dengan analisis parametrik berupa pengujian Two Way Anova. Dimana pada uji ini digunakan penilaian data olahan frekuensi risiko atau dampak risiko untuk mengetahui ada tidaknya pengaruh atau perbedaan persepsi dengan faktor lamanya pengalaman kerja dan tingkat pendidikan. Adapun hasil uji normalitas nilai residual standard dan uji homogenitas serta uji Two Way Anova adalah sebagai berikut:

Tabel 4. Hasil Uji Nilai Residual Standard untuk Frekuensi Risiko.

\begin{tabular}{lccccccc}
\hline \multicolumn{9}{c}{ Tests of Normality } \\
\hline & \multicolumn{3}{c}{ Kolmogorov-Smirnov ${ }^{\mathrm{a}}$} & \multicolumn{2}{c}{ Shapiro-Wilk } \\
\cline { 2 - 8 } & Statistic & df & Sig. & Statistic & df & Sig. \\
\hline Standard Residual & .108 & 33 & .200 & .966 & 33 & .372 \\
\hline
\end{tabular}

Tabel 5. Hasil Homogenitas Varians antara Lama Bekerja dan Tingkat Pendidikan terhadap Frekuensi Risiko.

\begin{tabular}{cccc}
\hline \multicolumn{4}{c}{ Dependent } \\
\hline $\mathrm{F}$ & df 1 & $\mathrm{df} 2$ & Sig. \\
\hline 1.942 & 9 & 23 & .096 \\
\hline
\end{tabular}

Tabel 6. Hasil Uji Nilai Residual Standard untuk Dampak Risiko.

\begin{tabular}{lcccrrr}
\hline \multicolumn{9}{c}{ Tests of Normality } & & \\
\hline & \multicolumn{3}{c}{ Kolmogorov-Smirnov $^{\mathrm{a}}$} & \multicolumn{3}{c}{ Shapiro-Wilk } \\
\cline { 2 - 7 } & Statistic & df & Sig. & Statistic & df & Sig. \\
\hline Standard Residual & .100 & 39 & $.200^{*}$ & .960 & 39 & .180 \\
\hline
\end{tabular}

Tabel 7. Hasil Homogenitas Varians antara Lama Bekerja dan Tingkat Pendidikan terhadap Dampak Risiko. Dependent Variable: Dampak_Risiko

\begin{tabular}{cccc}
\hline $\mathrm{F}$ & $\mathrm{df} 1$ & $\mathrm{df} 2$ & Sig. \\
\hline .861 & 10 & 28 & .578 \\
\hline
\end{tabular}

\section{Uji Validitas}

Uji validitas kuesioner utama dilakukan dua kali, yaitu validitas frekuensi dan validitas dampak dengan menggunakan program SPSS 24. Adapun hasil uji validitas kuesioner utama sebagai berikut:

Tabel 8. Hasil Uji Validitas Kuesioner Utama.

\begin{tabular}{cccccc}
\hline \multirow{2}{*}{ Variabel } & \multirow{2}{*}{ Rtabel } & \multicolumn{2}{c}{ Pearson Corelation } & \multicolumn{2}{c}{ Hasil Uji Validitas } \\
\cline { 3 - 6 } & & Frekuensi & Dampak & Frekuensi & Dampak \\
\hline X1 & 0,316 & 0,654 & 0,645 & Valid & Valid \\
X2 & 0,316 & 0,818 & 0,465 & Valid & Valid \\
X3 & 0,316 & 0,707 & 0,852 & Valid & Valid \\
X4 & 0,316 & 0,694 & 0,774 & Valid & Valid \\
X5 & 0,316 & 0,655 & 0,753 & Valid & Valid \\
X6 & 0,316 & 0,620 & 0,564 & Valid & Valid \\
X7 & 0,316 & 0,559 & 0,780 & Valid & Valid \\
X8 & 0,316 & 0,407 & 0,780 & Valid & Valid \\
\hline
\end{tabular}




\begin{tabular}{|c|c|c|c|c|c|}
\hline X9 & 0,316 & 0,524 & 0,804 & Valid & Valid \\
\hline X10 & 0,316 & 0,336 & 0,534 & Valid & Valid \\
\hline X11 & 0,316 & 0,589 & 0,749 & Valid & Valid \\
\hline $\mathrm{X} 12$ & 0,316 & 0,680 & 0,658 & Valid & Valid \\
\hline X13 & 0,316 & 0,668 & 0,603 & Valid & Valid \\
\hline X14 & 0,316 & 0,418 & 0,486 & Valid & Valid \\
\hline X15 & 0,316 & 0,335 & 0,622 & Valid & Valid \\
\hline X16 & 0,316 & 0,563 & 0,804 & Valid & Valid \\
\hline X17 & 0,316 & 0,836 & 0,845 & Valid & Valid \\
\hline X18 & 0,316 & 0,510 & 0,808 & Valid & Valid \\
\hline X19 & 0,316 & 0,486 & 0,316 & Valid & Valid \\
\hline $\mathrm{X} 20$ & 0,316 & 0,679 & 0,586 & Valid & Valid \\
\hline $\mathrm{X} 21$ & 0,316 & 0,563 & 0,872 & Valid & Valid \\
\hline X22 & 0,316 & 0,492 & 0,593 & Valid & Valid \\
\hline $\mathrm{X} 23$ & 0,316 & 0,486 & 0,873 & Valid & Valid \\
\hline X24 & 0,316 & 0,836 & 0,579 & Valid & Valid \\
\hline $\mathrm{X} 25$ & 0,316 & 0,651 & 0,534 & Valid & Valid \\
\hline X26 & 0,316 & 0,679 & 0,869 & Valid & Valid \\
\hline X27 & 0,316 & 0,486 & 0,590 & Valid & Valid \\
\hline X28 & 0,316 & 0,594 & 0,340 & Valid & Valid \\
\hline X29 & 0,316 & 0,591 & 0,869 & Valid & Valid \\
\hline X30 & 0,316 & 0,836 & 0,645 & Valid & Valid \\
\hline X31 & 0,316 & 0,353 & 0,579 & Valid & Valid \\
\hline X32 & 0,316 & 0,390 & 0,834 & Valid & Valid \\
\hline X33 & 0,316 & 0,563 & 0,335 & Valid & Valid \\
\hline X34 & 0,316 & 0,453 & 0,837 & Valid & Valid \\
\hline X35 & 0,316 & 0,327 & 0,766 & Valid & Valid \\
\hline X36 & 0,316 & 0,591 & 0,793 & Valid & Valid \\
\hline X37 & 0,316 & 0,494 & 0,335 & Valid & Valid \\
\hline X38 & 0,316 & 0,453 & 0,806 & Valid & Valid \\
\hline X39 & 0,316 & 0,675 & 0,664 & Valid & Valid \\
\hline $\mathrm{X} 40$ & 0,316 & 0,468 & 0,644 & Valid & Valid \\
\hline $\mathrm{X} 41$ & 0,316 & 0,803 & 0,511 & Valid & Valid \\
\hline $\mathrm{X} 42$ & 0,316 & 0,255 & 0,238 & Tidak Valid & Tidak Valid \\
\hline $\mathrm{X} 43$ & 0,316 & 0,707 & 0,814 & Valid & Valid \\
\hline X44 & 0,316 & 0,501 & 0,693 & Valid & Valid \\
\hline $\mathrm{X} 45$ & 0,316 & 0,525 & 0,335 & Valid & Valid \\
\hline $\mathrm{X} 46$ & 0,316 & 0,468 & 0,838 & Valid & Valid \\
\hline $\mathrm{X} 47$ & 0,316 & 0,382 & 0,611 & Valid & Valid \\
\hline $\mathrm{X} 48$ & 0,316 & 0,553 & 0,815 & Valid & Valid \\
\hline X49 & 0,316 & 0,460 & 0,504 & Valid & Valid \\
\hline $\mathrm{X} 50$ & 0,316 & 0,564 & 0,419 & Valid & Valid \\
\hline X51 & 0,316 & 0,635 & 0,772 & Valid & Valid \\
\hline X52 & 0,316 & 0,696 & 0,814 & Valid & Valid \\
\hline X53 & 0,316 & 0,776 & 0,640 & Valid & Valid \\
\hline X54 & 0,316 & 0,632 & 0,609 & Valid & Valid \\
\hline X55 & 0,316 & 0,679 & 0,579 & Valid & Valid \\
\hline X56 & 0,316 & 0,707 & 0,812 & Valid & Valid \\
\hline X57 & 0,316 & 0,146 & 0,164 & Tidak Valid & Tidak Valid \\
\hline X58 & 0,316 & 0,848 & 0,794 & Valid & Valid \\
\hline X59 & 0,316 & 0,654 & 0,803 & Valid & Valid \\
\hline X60 & 0,316 & 0,600 & 0,637 & Valid & Valid \\
\hline X61 & 0,316 & 0,565 & 0,793 & Valid & Valid \\
\hline X62 & 0,316 & 0,617 & 0,723 & Valid & Valid \\
\hline X63 & 0,316 & 0,603 & 0,840 & Valid & Valid \\
\hline X64 & 0,316 & 0,436 & 0,638 & Valid & Valid \\
\hline X65 & 0,316 & 0,630 & 0,749 & Valid & Valid \\
\hline X66 & 0,316 & 0,709 & 0,723 & Valid & Valid \\
\hline X67 & 0,316 & 0,555 & 0,568 & Valid & Valid \\
\hline
\end{tabular}


Hasil uji validitas kuesioner utama pada Tabel 8. menunjukan bahwa terdapat dua variabel yang harus dibuang karena terdapat hasil yang tidak valid (nilai $r$ hitung $<r$ tabel), yaitu variabel X42 dan variabel X57. Variabel yang sudah valid dipakai untuk uji reliabilitas.

\section{Uji Reliabilitas}

Uji reliabilitas kuesioner utama dilakukan juga dengan menggunakan program SPSS 24 yaitu dengan menggunakan metode stabilitas Cronbach's Alpha, sebagai berikut:

Tabel 9. Uji Reliabilitas Frekuensi.

\begin{tabular}{cc}
\hline \multicolumn{2}{c}{ Reliability Statistics } \\
\hline Cronbach's Alpha & N of Items \\
\hline .971 & 65 \\
\hline \\
Tabel 10. Uji Reliabilitas Dampak. \\
\hline \multicolumn{2}{c}{ Reliability Statistics } \\
\hline Cronbach's Alpha & N of Items \\
\hline .982 & 65 \\
\hline
\end{tabular}

Tabel 9. menunjukan bahwa hasil nilai reliabilitas frekuensi dengan menggunakan metode stabilitas Cronbach's Alpha yaitu 0,971 > 0,6 dan Tabel 10 nilai reliabilitas dampak yaitu 0,982 > 0,6. Hal ini menunjukkan bahwa nilai tersebut adalah reliabel.

\section{Analisis Risiko Metode AHP}

Langkah pertama dalam melakukan analisis ini adalah membuat matriks berpasangan untuk frekuensi risiko dan dampak risiko yang diperoleh berdasarkan penilaian setiap kriterianya ditentukan sesuai dengan tabel skala nilai dasar.

Tabel 11. Skala Nilai Dasar.

\begin{tabular}{cl}
\hline Skala & Keterangan \\
\hline 1 & Kedua elemen sama penting \\
3 & Elemen yang satu sedikit lebih penting daripada elemen yang lain \\
5 & Elemen yang satu lebih penting daripada elemen yang lainnya \\
7 & Satu elemen jelas lebih penting daripada elemen yang lainnya \\
9 & Satu elemen mutlak lebih penting daripada elemen yang lainnya \\
$2,4,6,8$ Nilai-nilai antara dua nilai pertimbangan yang berdekatan
\end{tabular}

Sumber: Saaty, 2008

Berikut ini merupakan matriks berpasangan untuk frekuensi risiko dan dampak risiko.

Tabel 12. Matriks Berpasangan Frekuensi Risiko.

\begin{tabular}{cccccc}
\hline & Sangat Tinggi & Tinggi & Sedang & Rendah & Sangat Rendah \\
\hline Sangat Tinggi & 1 & 3 & 5 & 7 & 9 \\
Tinggi & 0,33 & 1 & 3 & 5 & 7 \\
Sedang & 0,20 & 0,33 & 1 & 3 & 5 \\
Rendah & 0,14 & 0,20 & 0,33 & 1 & 3 \\
Sangat Rendah & 0,11 & 0,14 & 0,20 & 0,33 & 1 \\
Jumlah & 1,79 & 4,68 & 9,53 & 16,33 & 25,00 \\
\hline
\end{tabular}

Tabel 13. Matriks Berpasangan Dampak Risiko.

\begin{tabular}{cccccc}
\hline & Sangat Tinggi & Tinggi & Sedang & Rendah & Sangat Rendah \\
\hline Sangat Tinggi & 1 & 3 & 5 & 7 & 9 \\
Tinggi & 0,33 & 1 & 3 & 5 & 7 \\
Sedang & 0,20 & 0,33 & 1 & 3 & 5 \\
Rendah & 0,14 & 0,20 & 0,33 & 1 & 3 \\
Sangat Rendah & 0,11 & 0,14 & 0,20 & 0,33 & 1 \\
Jumlah & 1,79 & 4,68 & 9,53 & 16,33 & 25,00 \\
\hline
\end{tabular}


Tahapan selanjutnya adalah menentukan pembobotan matriks. Hasil pembobotan matriks diperoleh dari nilai prioritas tiap elemen matriks. Sebagai contoh nilai pada tabel matriks berpasangan dampak risiko untuk kriteria sangat tinggi dan sangat tinggi adalah 1, nilai tersebut dibagi dengan jumlah kolom yaitu 1,787 sehingga diperoleh hasil 0,560. Lanjutkan perhitungan untuk tiap kolom dengan cara yang sama. Setelah memperoleh bobot tiap elemen, hitung nilai prioritasnya dengan cara membagi jumlah bobot elemen tiap baris dengan jumlah elemen yaitu 5. Lakukan hal yang sama pada baris berikutnya sehingga diperoleh pembobotan matriks sebagai berikut.

Tabel 14. Bobot Matriks Frekuensi Risiko.

\begin{tabular}{cccccc}
\hline & Sangat Tinggi & Tinggi & Sedang & Rendah & Sangat Rendah \\
\hline Sangat Tinggi & 1 & 0,518 & 0,267 & 0,135 & 0,069 \\
\hline \multicolumn{6}{c}{ Tabel 15. Bobot Matriks Frekuensi Risiko. } \\
\hline & Sangat Tinggi & Tinggi & Sedang & Rendah & Sangat Rendah \\
\hline Sangat Tinggi & 1 & 0,518 & 0,267 & 0,135 & 0,069 \\
\hline
\end{tabular}

Tahapan selanjutnya adalah melakukan perhitungan konsistensi matriks yang diperoleh dari nilai vektor eigen. Nilai tersebut diperoleh dari hasil rata-rata dari jumlah perkalian matriks antara matriks pembobotan dengan matriks awal (matriks berpasangan). Setelah melakukan perhitungan nilai vektor eigen diperoleh hasil nilai vektor eigen sebesar 5,22 mendekati jumlah elemen (n) sebesar 5 dan nilai sisa vektor eigen sebesar 0,22 mendekati 0. Maka matriks tersebut konsisten.

Nilai konsistensi rasio (CR) yang didapat sebesar 0,05 yaitu cukup kecil atau dibawah $10 \%$ berarti hirarki konsisten dan tingkat akurasi tinggi.

\section{Nilai Lokal untuk Frekuensi Risiko dan Dampak Risiko}

Perhitungan nilai lokal diperoleh dengan cara mengalikan bobot elemen dengan jumlah responden yang menjawab kriteria elemen untuk tiap variabel faktor risiko tersebut. Setiap rata-rata nilai lokal frekuensi risiko (L) dan rata-rata nilai dampak risiko (I) digunakan untuk memperoleh nilai faktor risiko (FR).

\section{Nilai Peringkat dan Analisis Level Risiko}

Dari perhitungan nilai lokal frekuensi dan dampak risiko, selanjutnya dapat ditentukan kategori risiko dan peringkat risiko sebagai berikut:

Tabel 16. Nilai Faktor Risiko, Kategori Risiko dan Peringkat Risiko.

\begin{tabular}{cccccc}
\hline Variabel & $\mathrm{L}$ & $\mathrm{I}$ & $\mathrm{FR}$ & Risk Rank & Risk Level \\
\hline X1 & 0,172 & 0,539 & 0,618 & 11 & Medium \\
X2 & 0,172 & 0,536 & 0,616 & 12 & Medium \\
X3 & 0,357 & 0,367 & 0,593 & 18 & Medium \\
X4 & 0,369 & 0,246 & 0,524 & 32 & Medium \\
X5 & 0,167 & 0,209 & 0,341 & 56 & Low \\
X6 & 0,152 & 0,214 & 0,334 & 59 & Low \\
X7 & 0,157 & 0,340 & 0,443 & 45 & Medium \\
X8 & 0,154 & 0,226 & 0,345 & 54 & Low \\
X9 & 0,180 & 0,353 & 0,470 & 43 & Medium \\
X10 & 0,158 & 0,652 & 0,707 & 5 & High \\
X11 & 0,155 & 0,209 & 0,332 & 60 & Low \\
X12 & 0,205 & 0,242 & 0,397 & 47 & Low \\
X13 & 0,180 & 0,173 & 0,322 & 63 & Low \\
X14 & 0,158 & 0,150 & 0,284 & 65 & Low \\
X15 & 0,157 & 0,173 & 0,303 & 64 & Low \\
X16 & 0,192 & 0,571 & 0,654 & 7 & Medium \\
X17 & 0,182 & 0,411 & 0,518 & 35 & Medium \\
X18 & 0,190 & 0,560 & 0,643 & 9 & Medium \\
X19 & 0,171 & 0,833 & 0,861 & 2 & High \\
X20 & 0,206 & 0,501 & 0,604 & 16 & Medium \\
X21 & 0,192 & 0,512 & 0,605 & 15 & Medium \\
X22 & 0,215 & 0,451 & 0,569 & 23 & Medium \\
X23 & 0,171 & 0,474 & 0,564 & 24 & Medium \\
\hline
\end{tabular}




\begin{tabular}{|c|c|c|c|c|c|}
\hline X24 & 0,182 & 0,207 & 0,351 & 51 & Low \\
\hline $\mathrm{X} 25$ & 0,207 & 0,174 & 0,345 & 53 & Low \\
\hline X26 & 0,206 & 0,499 & 0,602 & 17 & Medium \\
\hline $\mathrm{X} 27$ & 0,171 & 0,420 & 0,519 & 33 & Medium \\
\hline $\mathrm{X} 28$ & 0,172 & 0,343 & 0,456 & 44 & Medium \\
\hline X29 & 0,175 & 0,499 & 0,587 & 19 & Medium \\
\hline X30 & 0,182 & 0,182 & 0,331 & 61 & Low \\
\hline X31 & 0,175 & 0,207 & 0,346 & 52 & Low \\
\hline X32 & 0,180 & 0,460 & 0,557 & 26 & Medium \\
\hline X33 & 0,192 & 0,368 & 0,489 & 40 & Medium \\
\hline X34 & 0,178 & 0,401 & 0,508 & 37 & Medium \\
\hline X35 & 0,183 & 0,441 & 0,544 & 29 & Medium \\
\hline X36 & 0,175 & 0,455 & 0,550 & 27 & Medium \\
\hline X37 & 0,169 & 0,377 & 0,482 & 41 & Medium \\
\hline X38 & 0,178 & 0,401 & 0,508 & 37 & Medium \\
\hline X39 & 0,188 & 0,456 & 0,559 & 25 & Medium \\
\hline $\mathrm{X} 40$ & 0,205 & 0,514 & 0,613 & 13 & Medium \\
\hline X41 & 0,180 & 0,210 & 0,352 & 50 & Low \\
\hline X43 & 0,203 & 0,418 & 0,536 & 30 & Medium \\
\hline X44 & 0,222 & 0,493 & 0,606 & 14 & Medium \\
\hline $\mathrm{X} 45$ & 0,177 & 0,368 & 0,479 & 42 & Medium \\
\hline X46 & 0,205 & 0,563 & 0,653 & 8 & Medium \\
\hline X47 & 0,167 & 0,192 & 0,327 & 62 & Low \\
\hline $\mathrm{X} 48$ & 0,159 & 0,499 & 0,579 & 21 & Medium \\
\hline X49 & 0,165 & 0,206 & 0,337 & 58 & Low \\
\hline X50 & 0,098 & 0,913 & 0,922 & 1 & High \\
\hline X51 & 0,187 & 0,645 & 0,711 & 4 & High \\
\hline X52 & 0,187 & 0,418 & 0,527 & 31 & Medium \\
\hline X53 & 0,183 & 0,232 & 0,373 & 49 & Low \\
\hline X54 & 0,115 & 0,739 & 0,769 & 3 & High \\
\hline X55 & 0,220 & 0,268 & 0,429 & 46 & Medium \\
\hline X56 & 0,203 & 0,225 & 0,383 & 48 & Low \\
\hline X58 & 0,178 & 0,197 & 0,340 & 57 & Low \\
\hline X59 & 0,172 & 0,547 & 0,624 & 10 & Medium \\
\hline X60 & 0,159 & 0,408 & 0,502 & 39 & Medium \\
\hline X61 & 0,155 & 0,466 & 0,549 & 28 & Medium \\
\hline X62 & 0,190 & 0,481 & 0,580 & 20 & Medium \\
\hline X63 & 0,157 & 0,220 & 0,342 & 55 & Low \\
\hline X64 & 0,610 & 0,133 & 0,662 & 6 & Medium \\
\hline X65 & 0,391 & 0,209 & 0,519 & 34 & Medium \\
\hline X66 & 0,402 & 0,179 & 0,508 & 36 & Medium \\
\hline X67 & 0,433 & 0,245 & 0,572 & 22 & Medium \\
\hline
\end{tabular}

Tabel 17. Kategori Risiko.

\begin{tabular}{ccc}
\hline Nilai FR & Kategori & Langkah Penanganan \\
\hline$>0,7$ & Risiko Tinggi & Harus dilakukan penurunan tingkat risiko \\
$0,4-0,7$ & Risiko Sedang & Langkah perbaikan dibutuhkan dalam jangka waktu tertentu \\
$<0,4$ & Risiko Rendah & Langkah perbaikan bila memungkinkan \\
\hline Sumber: Risk Management Guidelines 2006
\end{tabular}

Selanjutnya dilakukan respon risiko dengan cara memberikan solusi korektif dan solusi preventif terhadap faktor risiko dominan.

\section{KESIMPULAN}

Berdasarkan pembahasan yang telah disampaikan dapat disimpulkan beberapa hal yang menjawab tujuan dari penelitian yaitu pertama terdapat 5 variabel risiko tinggi (high), 41 variabel risiko sedang (medium), dan 19 variabel risiko rendah (low). Risiko tinggi (high) yang terjadi adalah pada variabel X10, X19, X50, X51, dan X54. 
Uraian risiko dominan dan respon pengendalian risiko dengan cara tindakan preventif dan korektif didapat masukan oleh para pakar yaitu faktor risiko pertama yaitu Variabel (X10) terjadinya kebakaran BBM. Tindakan preventif yang dapat dilakukan yaitu saat pengisian BBM dilarang merokok, menggunakan HP, dan menyalakan api dalam bentuk apapun. Memastikan pompa elektrik berfungsi dengan baik. Memastikan selang BBM terpasang dengan benar dan dalam kondisi layak pakai. Memastikan tangki BBM diletakkan pada permukaan yang keras dan rata. Mematikan mesin kendaraan. Adapun tindakan korektif yang dapat dilakukan yaitu memadamkan api dengan APAR, jika memungkinkan. Mensterilisasi area. Evakuasi secepatnya bagi karyawan/pekerja. Menyelamatkan dokumen-dokumen atau asset yang penting.

Faktor risiko kedua yaitu Variabel (X19) terkena utilitas dibawahnya (pipa gas/air). Tindakan preventif yang dapat dilakukan yaitu memastikan area galian diberi rambu peringatan (misal: hati-hati) dan diproteksi dilarang melintas. Survey lapangan. Memastikan operator alat berat yang berkompeten, berpengalaman dan memiliki SIO (Surat Ijin Operasi). Melakukan proteksi jalur pipa gas/air dengan menggunakan safety line. Adapun tindakan korektif yang dapat dilakukan yaitu pengawasan pekerjaan mesti dilakukan secara teratur dan berkelanjutan. Mensterilisasi area. Pemberian rambu dan peringatan ulang agar tidak terjadi kecelakaan lagi. Segera menuju ke area berkumpul evaluasi. Perhatikan arah angin, berjalanlah ke arah yang berlawanan, jangan panik.

Faktor risiko ketiga yaitu Variabel (X50) girder yang diangkat terjatuh. Tindakan preventif yang dapat dilakukan yaitu memastikan sling belt dalam kondisi baik dan terpasang dengan benar. Pemasangan rambu-rambu peringatan (misalnya hati-hati, dilarang melewati kawasan proyek, ada orang bekerja, dll). Memastikan hook terkunci. Memastikan rigger berkompeten. Bebaskan area pengangkatan dari orang. Adapun tindakan korektif yang dapat dilakukan yaitu pekerja dibawa ke klinik/ kantor K3 dan jika parah segera dilarikan ke rumah sakit terdekat. Peringatan ulang agar pekerja tidak tertimpa material lagi. Komunikasi operator dan mandor/rigger lebih diperhatikan.

Faktor risiko keempat yaitu Variabel (X51) pekerja tertimpa pipa tremi/concrete pump. Tindakan preventif yang dapat dilakukan yaitu memeriksa sling belt sebelum bekerja. Memastikan alat layak digunakan. Memastikan pengikatan terkunci. Memastikan Rigger kompeten. Bebaskan area pengangkatan dari orang. Adapun tindakan korektif yang dapat dilakukan yaitu pekerja dibawa ke klinik/kantor K3 dan jika parah segera dilarikan ke rumah sakit terdekat. Peringatan ulang agar pekerja tidak tertimpa material lagi. Komunikasi operator dan mandor/rigger lebih diperhatikan.

Faktor risiko kelima yaitu Variabel (X54) pekerja jatuh dari ketinggian. Tindakan preventif yang dapat dilakukan yaitu memastikan kondisi pekerja dalam keadaan sehat. Pekerja harus sudah cakap/ahli. Memastikan pekerja menggunakan APD (Alat Pelindung Diri) misalnya body harness, sepatu boot, helm dan sarung tangan. Adapun tindakan korektif yang dapat dilakukan yaitu pekerja dibawa ke klinik/kantor K3 dan jika parah segera dilarikan ke rumah sakit terdekat. Peringatan ulang agar pekerja tidak tertimpa material lagi.

\section{UCAPAN TERIMA KASIH}

Saya ucapkan terimakasih kepada Bapak Dr. Andi T. Tenriajeng, MT. selaku dosen pembimbing penelitian. Kepada orang tua dan adik yang senantiasa mencurahkan perhatian, dukungan dan doa. Kepada rekan-rekan yang telah memberikan semangat dan membantu dalam penelitian. Sehingga saya dapat menyelesaikan penelitian ini.

\section{DAFTAR PUSTAKA}

A Guide to the Project Management Body of Knowledge (PMBOK Guide). 2008. $4^{\text {th }}$ Edition.

Anonim. 2015, Rencana Mutu Kesehatan dan Keselamatan Kerja Lingkungan. PT. Hutama Karya Infrastruktur, Jakarta

Bayu, Made. 2017, Pengaruh Pengetahuan Keselamatan dan Kesehatan Kerja Terhadap Perilaku Pekerja Konstruksi pada Proyek Jalan Tol Nusa Dua, Universitas Udayana, Denpasar.

Ervianto, Wulfram I. 2005, Manajemen Proyek Konstruksi, Edisi Revisi, ANDI, Yogyakarta.

Hartono, Widi. 2015, Analisis Risiko Konstruksi Struktur Atas dengan Metode Analythical Hierarchy Process, Universitas Sebelas Maret.

Januar, Anhar. M. 2013, Pengaruh Kebijakan Keselamatan Dan Kesehatan Kerja (K3) Terhadap Kinerja Karyawan Proyek Konstruksi Pada PT. Pembangunan Perumahan, Makasar. 
Jati, Ibrahim Kusuma. 2010, Pelaksanaan Program K3 Karyawan PT. Bitratex Industries Semarang. Universitas Diponegoro, Semarang.

Kerzner, Harold. Project Management A System Approach to Planning, Schedulling and Controlling. 2009. $10^{\text {th }}$ Edition.

Komaraningsih, Alifah. 2013, Manajemen Risiko Keselamatan Kerja pada Pekerjaan Bangunan Atas di Proyek Pembangunan Jalan Layang Tol Bogor Outer Ring Road (BORR) Seksi 2A, Universitas Indonesia, Jakarta.

Munggaran, Ahmad. 2016, Kajian Manajemen Risiko Keselamatan dan Kesehatan Kerja pada Proyek Gedung, Universitas Gunadarma, Jakarta.

Peraturan Menteri PU No. 05/PRT/M/2014 tentang Sistem Manajemen Keselamatan dan Kesehatan Kerja.

Saaty, Thomas L. 1986, Decision Making for Leaders: The Analytical Hierarchy Process for Decisions in Complex World, University of Pittsburgh, Pitssburgh.

Safira, A Nadya. 2014, Analisis Risiko yang Berpengaruh Terhadap Kinerja Proyek Pada Pembangunan Hotel Batiqa Palembang, Universitas Sriwijaya, Sumatera Selatan.

Setiawan, Deby E. S. 2015, Pengaruh Pengaruh Keselamatan dan Kesehatan Kerja Terhadap Kinerja Pekerja Proyek Konstruksi Samasta Moevenpick Hotel dan Resort Jimbaran Bali (PT. Tata Mulia Nusantara), Jember.

Siregar, S. 2017, Metode Penelitian Kuantitatif Dilengkapi dengan Perbandingan Perhitungan Manual \& SPSS, Kencana, Jakarta.

Sugiyono. 2010, Metode Penelitian Bisnis (Pendekatan Kuantitatif, Kualitatif, dan R\&D), AlfaBeta, Bandung.

Widiarti, Devi Noverina. 2012, Faktor-faktor Risiko yang Berpengaruh Pada Perubahan Lingkup Pekerjaan Struktur Atas dan Arsitekur Bangunan Gedung Bertingkat di Jakarta yang Berdampak Terhadap Kinerja Waktu Pelaksanaan, Universitas Indonesia, Jakarta.

Yuni, Wieke Christina, dkk. 2012, Pengaruh Budaya K3 Terhadap Kinerja Proyek Konstruksi, Universitas Brawijaya Malang, Malang. 